\title{
MEMBANGKITKAN PRESTASI BELAJAR MATEMATIKA SISWA SEKOLAH DASAR MELALUI MEDIA SUDUT SIKU-SIKU
}

\author{
Nining Sriani ${ }^{1}$, Srigati $^{2}$, Siti Mushofiah ${ }^{3}$, Imam Maliki $^{4}$ \\ ${ }^{1}$ SDN Kepuhrejo, ${ }^{2}$ SDN Wanengpaten, ${ }^{3}$ SDN Turus, ${ }^{4}$ SDN Plosorejo 1 \\ Email: ${ }^{1}$ srianinining@yahoo.com, ${ }^{2}$ srigati23@gmail.com, \\ ${ }^{3}$ sitimushofiah@gmail.com, ${ }^{4}$ imam_maliki@yahoo.co.id
}

\begin{abstract}
Abstrak: Dalam proses pembelajaran yang menyangkut materi, metode, media, dan alat pembelajaran harus mengalami perubahan ke arah pembaharuan (inovasi). Dengan adanya inovasi seorang guru dituntut untuk lebih kreatif dan inovatif. Seorang guru sangat diperlukan dalam menghadapi prestasi belajar siswa, tugas guru tidak hanya mengajar, tetapi juga mendidik, mengasuh, membimbing dan membentuk kepribadian siswa guna menyiapkan dan mengembangkan sumber daya manusia. Kesalahan guru dalam mengajar akan mengakibatkan bergesernya fungsi guru secara perlahan-lahan, sehingga akan mengakibatkan hubungan antara guru dan siswa yang semula saling membutuhkan akan berubah menjadi hubungan yang saling acuh tak acuh, tidak membahagiakan dan membosankan.
\end{abstract}

Kata Kunci: prestasi belajar, matematika, sudut siku-siku

Guru merupakan sosok yang begitu dihormati karena memiliki andil yang sangat besar terhadap keberhasilan pembelajaran di sekolah. Guru sangat berperan dalam membantu perkembangan peserta didik untuk mewujudkan tujuan hidupnya secara optimal. Ketika orang tua mendaftarkan anaknya ke sekolah, pada saat itu juga orang tua menaruh harapan terhadap guru, agar anaknya dapat berkembang secara optimal (Mulyasa, 2005:10). Minat, bakat, kemampuan, dan potensi yang dimiliki peserta didik tidak akan dapat berkembang secara optimal tanpa bantuan guru. Dalam kaitan ini guru perlu memperhatikan peserta didik secara individual. Tugas guru tidak hanya mengajar, namun juga mendidik, mengasuh, membimbing, dan membentuk kepribadian siswa guna menyiapkan dan mengembangkan sumber daya manusia.

Indonesia harus melakukan reformasi dalam dunia pendidikan, yaitu dengan menciptakan sistem pendidikan yang lebih komprehensif dan fleksibel, sehingga para lulusan dapat berfungsi secara efektif dalam kehidupan masyarakat global demokratis. Oleh karena itu, pendidikan harus dirancang sedemikian rupa agar memungkinkan para anak didik dapat mengembangkan potensi yang dimiliki secara alami dan kreatif dalam suasana penuh kebebasan, kebersamaan dan tanggung jawab. Selain itu, pendidikan harus dapat menghasilkan lulusan yang bisa memahami masyarakatnya dengan segala faktor yang dapat mendukung mencapai sukses ataupun penghalang yang menyebabkan kegagalan di dalam kehidupan bermasyarakat.

Hal tersebut salah satunya ditentukan oleh sikap profesionalisme guru; (1) masih banyak guru yang tidak menekuni profesinya secara total; (2) rentan dan rendahnya kepatuhan guru terhadap norma dan etika profesi keguruan; (3) 
pengakuan terhadap ilmu pendidikan dan keguruan masih setengah hati dari pengambilan kebijakan dan pihak-pihak terlibat. (4) perbedaan pendapat tentang proporsi materi ajar yang diberikan guru, (5) meningkatkan profesionalisme guru dalam menyampaikan materi pelajaran (Suara Guru, 2012)

Selain hal tersebut juga ditentukan oleh media pembelajaran yang sesuai dengan materi yang telah direncanakan guru. Namun demikian di masa sekarang guru sepantasnya mulai mengupayakan profesionalismenya. Pada kesempatan ini materi yang akan dibahas tentang jenis dan besar sudut. Standar kompetensi: memahami unsur dan besar sudut, Kompetensi dasar: mengidentifikasi berbagai bangun datar sederhana menurut sifat dan unsurnya. Indikator: setelah membuat sudut siku-siku siswa dapat menentukan sudut lancip, sudut tumpul dan sudut siku-siku dengan benar; tujuan pembuatan: dengan menggunakan sudut siku-siku siswa dapat menentukan sudut lancip, sudut siku-siku, sudut tumpul dengan teliti dan benar.

Menurut Prasetyo Utomo (2006), keuntungan yang bisa diraih guru dengan kurikulum 2006 ini adalah keleluasaan memilih bahan ajar dan peserta didik diharapkan dapat mengembangkan potensinya sesuai dengan kemampuan, kebutuhan dan minatnya. Guru dapat memusatkan perhatian pada pengembangan peserta didik dengan menyediakan aneka ragam kegiatan belajar mengajar ( Asmani, 2010).

\section{PEMBAHASAN}

\section{Membangkitkan Prestasi Belajar}

Membangkitkan Prestasi Belajar Matematika Siswa Definisi membangkitkan menurut KBBI (Kamus Besar Bahasa Indonesia) adalah (1) membangunkan (orang tidur); (2) menghidupkan kembali orang mati; (3) mengangkat dan menaikkan pedang di udara; (3) membangkit untuk, mengangkat (tt jemuran, cerek). Guru harus berupaya untuk meningkatkan prestasi belajar siswa diantaranya meningkatkan kualifikasi dan persyaratan jenjang pendidikan yang lebih tinggi dan merencanakan pembelajaran serta menggunakan media pembelajaran yang sesuai dengan materi yang akan disampaikan.

\section{Prestasi}

Pengertian prestasi adalah hasil nilai yang dicapai yang telah atau dilakukan ataupun dikerjakan. Hadari Nabawi (1981:100) mengemukakan pengertian prestasi sebagai keberhasilan murid dalam mempelajaari materi pembelajaran di sekolah yang dinyatakan dalam bentuk nilai/skor dari hasil tes mengenai sejumlah pelajaran tertentu. Hasan Sadly (1977:904) mengemukakan pengertian prestasi adalah hasil yang dicapai oleh tenaga atau daya kerja seseorang dalam waktu tertentu. Sedangkan Adi Marimba (1978:143) mengatakan prestasi adalah kemampuan seseorang atau kelompok yang secara langsung dapat di ukur.

\section{Belajar}

Pengertian belajar menurut pendapat Sumadi Surya brata (1984:251) adalah (1) belajar adalah memberi perubahan dalam arti behavional (changes 
actual maupun potensial); (2) belajar adalah perubahan pada pokoknya, didapatkanya suatu kecakapan baru. Pengertian belajar menurut Mohamad Ali (1986:31), Belajar adalah berusaha berlatih untuk mendapat pengetahuan. Belajar berhubungan dengan perubahan tingkah laku seseorang terhadap sesuatu situasi tertentu yang disebabkan oleh pengalamannya yang berulang-ulang dalam situasi itu dimana perubahan tingkah laku itu tidak dapat dijelaskan atau dasar kecenderungan respon pembawaan, kematangan atau keadaan sesaat seseorang (dalam Thamrin dan Nasution, 1986:32).

Belajar adalah perubahan yang relatif permanen dalam perilaku atau potensi perilaku sebagai hasil dari pengalaman atau latihan yang diperkuat. Belajar merupakan akibat adanya interaksi antara stimulus dan respon. Seseorang dianggap telah belajar sesuatu jika dia dapat menunjukkan perubahan perilakunya. Menurut Hilgard dalam (Sumardi Suryabrata, 1984:252) belajar merupakan proses perbuatan yang dilakukan dengan sengaja, yang kemudian menimbulkan perubahan, yang keadaannya berbeda dari perubahan yang ditimbulkan oleh lainnya. Sifat perubahannya relatif permanen, tidak akan kembali kepada keadaan semula. Tidak bisa diterapkan pada perubahan akibat situasi sesaat, seperti perubahan akibat kelelahan, sakit, mabuk, dan sebagainya. Sedangkan Gagne (1977), belajar merupakan sejenis perubahan yang diperlihatkan dalam perubahan tingkah laku, yang keadaaannya berbeda dari sebelum individu berada dalam situasi belajar dan sesudah melakukan tindakan yang serupa itu. Perubahan terjadi akibat adanya suatu pengalaman atau latihan. Berbeda dengan perubahan sertamerta akibat refleks atau perilaku yang bersifat naluriah.

\section{Siswa}

Siswa adalah komponen masukan dalam sistem pendidikan, yang selanjutnya diproses dalam proses pendidikan, sehingga menjadi manusia yang berkualitas sesuai dengan tujuan pendidikan nasional. Sebagai suatu komponen pendidikan, siswa dapat ditinjau dari berbagai pendekatan, antara lain: pendekatan social, pendekatan psikologis, dan pendekatan edukatif/pedagogis.

Pendekatan sosial, siswa adalah anggota masyarakat yang sedang disiapkan untuk menjadi anggota masyarakat yang lebih baik. Sebagai anggota masyarakat, dia berada dalam lingkungan keluarga, masyarakat sekitarnya, dan masyarakat yang lebih luas. siswa perlu disiapkan agar pada waktunya mampu melaksanakan perannya dalam dunia kerja dan dapat menyesuaikan diri dari masyarakat. Kehidupan bermasyarakat itu dimulai dari lingkungan keluarga dan dilanjutkan di dalam lingkungan masyarakat sekolah. Dalam konteks inilah, siswa melakukan interaksi dengan rekan sesamanya, guru-guru, dan masyarakat yang berhubungan dengan sekolah. Dalam situasi inilah nilai-nilai social yang terbaik dapat ditanamkan secara bertahap melalui proses pembelajaran dan pengalaman langsung.

Pendekatan Psikologis, siswa adalah suatu organisme yang sedang tumbuh dan berkembang. siswa memiliki berbagai potensi manusiawi, seperti: bakat,minat, kebutuhan, social-emosional-personal, dan kemampuan jasmaniah. Potensi-potensi itu perlu dikembangkan melalui proses pendidikan dan pembelajaran di sekolah, sehingga terjadi perkembangan secara menyeluruh 
menjadi manusia seutuhnya. Perkembangan menggambarkan perubahan kualitas dan abilitas dalam diri seseorang, yakni adanya perubahan dalam struktur, kapasitas, fungsi, dan efisiensi. Perkembangan itu bersifat keseluruhan, misalnya perkembangan intelegensi, sosial, emosional, spiritual, yang saling berhubungan satu dengan lainnya.

Pendekatan edukatif/paedagogis, pendekatan pendidikan menempatkan siswa sebagai unsur penting, yang memiliki hak dan kewajiban dalam rangka sistem pendidikan menyeluruh dan terpadu. Pengertian Siswa Menurut Wikipedia siswa adalah anggota masyarakat yang berusaha mengembangkan potensi diri melalui proses pembelajaran pada jalur pendidikan baik pendidikan formal maupun pendidikan nonformal, pada jenjang pendidikan dan jenis pendidikan tertentu.

Istilah Siswa dalam dunia pendidikan yaitu (1) siswa/siswi adalah istilah bagi peserta didik pada jenjang pendidikan dasar dan menengah, (2) mahasiswa/mahasiswi adalah istilah umum bagi peserta didik pada jenjang pendidikan tinggi, (3) warga belajar adalah istilah bagi peserta didik pada jalur pendidikan non formal seperti Pusat Kegiatan Belajar Masyarakat (PKBM), baik paket A, paket B, paket C, (4) pelajar adalah istilah lain yang digunakan peserta didik yang mengikuti pedidikan formal tingkat dasar maupun pedidikan formal tingkat menengah, (5) murid adalah istilah lain peserta didik, (6) santri adalah istilah bagi peserta didik suatu pesantren atau sekolah-sekolah salafiyah

\section{Media Pembelajaran}

Kata media berasal dari kata mediumyang secara harfiah mempunyai arti perantara atau pengantar. Pengertian media pembelajaran yang diungkapkan oleh Djamarah (1995:136) menurutnya media adalah alat bantu apa saja yang dapat dijadikan sebagai penyalur pesan guna mencapai tujuan pembelajaran. Ada banyak sekali jenis media yang sudah dikenal dan digunakan dalam penyampaian informasi dan pesan-pesan pembelajaran. Setiap jenis media pembelajaran tersebut dapat pula dikelompokkan sesuai dengan karakteristik dan sifat-sifatnya. Karena sampai saat ini belum ada kesepakatan yang baku dalam mengelompokkan media, maka banyak tenaga ahli yang mengelompokkan atau membuat klasifikasi media sesuai dengan sudut mana mereka memandang dan menilai media tersebut.

Berikut beberapa penggolongan media pembelajaran menurut para ahli yaitu (1) dilihat dari sifat fisiknya media dapat dibedakan menjadi (a) gambar diam, baik dalam bentuk teks, buletin, papan display, slide, film strip, atau overhead proyektor (b) gambar gerak, baik hitam putih maupun berwarna, baik yang bersuara maupun tidak bersuara (c) rekaman bersuara, baik dalam kaset maupun piringan hitam (d) televisi, baik hitam putih maupun berwarna (e) benda, baik benda hidup, simulasi, maupun model (f) instruksional berprogram ataupun CAI (Computer Asisten Instruction), termasuk didalamnya komputer, kalkulator, dan media elektronik lainnya; (2) dilihat dari jenisnya media dapat dibedakan menjadi (a) media audio (b) media visual (c) media audio visual; (3) dilihat dari daya liputnya media dapat dibedakan menjadi (a)media dengan daya liput luas dan serentak (b) media dengan daya liput yang terbatas oleh ruang dan tempat (c) 
media pengajaran individual; (4) dilihat dari bahan penbuatannya, media dapat dibedakan menjadi (a) media sederhana murah dan mudah memperolehnya (b) media kompleks (5) dilihat dari bentuknya, media dapat dibedakan menjadi (a) mdia grafis (dua dimensi) (b) media tiga dimensi (c) media elektronik.

Media pembelajaran sebagai alat bantu dalam proses belajar dan pembelajaran matematika adalah kenyataan yang tidak bisa kita pungkiri keberadaannya. Dengan media pembelajaran tugas orang tua atau guru ringan. Pada kegiatan belajar mengajar materi pembelajaran matematika yang terkesan rumit dan kompleks tanpa bantuan media tidak dapat dengan mudah dicerna dan dipahami siswa. Setiap materi pembelajaran mempunyai tingkat kesukaran yang bervariasi, ada materi pembelajaran yang tidak memerlukan media pembelajaran, tetapi ada juga materi yang memerlukan media pembelajaran. Materi yang memiliki tingkat kesukaran yang tinggi tentu sulit untuk dipahami. Pada kondisi seperti ini menggunakan media atau alat bantu untuk memudahkan belajar matematika.

Adapun tujuan dari penggunaan alat bantu matematika ini antara lain (1) mengembangkan kemampuan berpikir matematika secara kreatif, bagi sebagian anak, matematika tampak seperti suatu sistem yang kaku yang hanya berisi simbol-simbol dan sekumpulan dalil yang dipecahkan, padahal matematika memiliki banyak cara untuk mengembangkan kreativitas; (2) mengembangkan sikap menguntungkan yaitu berpikir secara matematis, biasanya akan membuat suasana pembelajaran matematika di kelas sedemikian rupa sehingga siswa dapat menyukai pelajaran tersebut, mmisalnya menyajikan matematika melalui pengalaman yang akrab dengan kehidupannya, shingga suasana semacam ini merupakan salah satu cara yang dapat membuat siswa memperoleh kepercayaan diri dalam belajar matematika;(3) menunjang matematika di luar kelas, yaitu dengan menunjukkan penerapan matematika dalam keadaan sebenarnya, sehingga siswa dapat menghubungkan pengalaman belajar dengan pengalaman-pengalaman kehidupan sehari-hari, dengan menggunakan ketrampilan masing-masing siswa dapat menyelidiki atau mengamati benda-benda disekitarnya kemudian mengorganisirnya untuk memecahkan suatu masalah; (4) memberikan motivasi dan memudahkan abstraksi siswa, dengan alat bantu siswa diharapkan dapat memperoleh pengalaman-pengalaman baru yang menyenangkan, sehingga dapat menghubungkannya dengan matematika yang bersifat abstrak (Putra, 2012).

\section{SUDUT}

Pengertian sudut menurut wikipedia bahasa Indonesia Sudut dalam geometri adalah besaran rotasi suatu ruas garis dari satu titik pangkalnya ke posisi yang lain. Selain itu, dalam bangun dua dimensi yang beraturan, sudut dapat pula diartikan sebagai ruang antara dua buah ruas garis lurus yang saling berpotongan. Besar sudut pada lingkaran $360^{\circ}$. Besar sudut pada segitiga siku-siku $180^{\circ}$. Besar sudut pada persegi/segi empat $360^{\circ}$. Untuk mengukur sudut dapat digunakan busur derajat. Tiap sudut segitiga sama sisi masing masing $60^{\circ}$, karena semua sudutnya sama besar maka $180^{\circ}: 3=60^{\circ}$. Sedangkan tiap sudut persegi $90^{\circ}$ karena semua sudutnya juga sama besar maka $360^{\circ}: 4=90^{\circ}$. 
Sudut adalah istilah yang sangat penting dan memiliki beberapa definisi yaitu (1) bentuknya terbuat dari 2 garis lurus yang bertemu disebuah titik; (2) Membuat jarak di antara 2 garis tersebut; (3) Jumlah ukuran 2 jarak pada busur; (4) Titik sudut adalah ujung kedua garis itu akan membentuk sebuah sudut. Memberi nama untuk sudut dengan berbagai karakteristik yaitu (1) Sudut 0 tidak memiliki jarak antara kedua garis; (2) sudut lancip adalah sudut antara 0 dan 89 derajat; (3) Sudut siku-siku adalah sudut 90 derajat .Dua garis yang membentuk sudut 90 derajat jika tegak lurus dengan yang lain.Pembentukan simbol sudut adalah potongan kotak.Simbol itu menunjukkan jika kamu bekerja dengan sudut siku-siku; (4) sudut tumpul adalah sudut antara 91 dan 179 derajat; (5) sudut lurus adalah sudut yang besarnya 180 derajat ; (6) sudut pusat adalah sudut yang memiliki titik sudut yang terletak ditengah lingkaran; (7) sudut bersebelahan adalah sudut yang memiliki titik sudut yang sama dan satu bagian sisi yang sama (bersebelahan berarti dekat); (8) Sudut yang berseberangan dibentuk oleh 2 garis lurus menyilang dan selalu sama.

Sudut yang sering digunakan dalam perdagangan adalah sudut 90. Itu dapat membantu dalam pemahaman mengapa demikian. Jika 2 garis disilangkan, maka membentuk 4 sudut. Jumlah dari keempat sudut itu adalah 360. Garis utama dari jangka adalah 2 garis lurus yang mana jika 2 garis tersebut disilangkan masing-masing besar sudutnya adalah 90. Sebagian besar dan perusahaanperusahaan mengatakan untuk membuat garis sepanjang garis utama dari jangka. Jika 2 garis disilangkan, dari keempat sudut yang terbentuk masing-masing besarnya sama jika pada setiap sudutnya besarnya 90 . Sudut 90 biasa disebut sudut siku-siku. Sudut siku-siku biasanya terdapat pada bangun datar seperti segitiga siku-siku, persegi panjang dan persegi

Derajat (secara lengkap, derajat busur), biasanya disimbolkan dengan ${ }^{\circ}$, adalah ukuran sudut yang dapat dibentuk pada sebuah bidang datar, menggambarkan 1/360 dari sebuah putaran penuh. Artinya, besar 1 derajat adalah satu juring pada lingkaran yang dibagi menjadi 360 buah juring yang besarnya sama. Jika sudut tersebut dinyatakan terhadap sebuah meridian referensi, sudut tersebut menunjukkan sebuah lokasi pada sebuah lingkaran besar sebuah bola (seperti Bumi, Mars, atau bola langit). Awal mula lingkaran dibagi atas $360^{\circ}$ berasal dari kerajaan Babilonia Kuno karena sistem bilangan Babilonia Kuno menggunakan bilangan yang berbasis 60 . Sedangkan kita saat ini terbiasa menggunakan sistem bilangan berbasis $10.1^{\circ}$ sama dengan 60 menit (ditulis 60') dan 1' sama dengan 60 detik (ditulis 60"). Derajat dan satuan-satuan pembaginya adalah satu-satunya satuan yang penulisan angka dan simbol satuannya tidak dipisah (contoh $15^{\circ} 30^{\prime}$, bukan $15^{\circ} 30^{\prime}$ ).

Sudut terbentuk dari 2 (dua) sinar garis yang memiliki titik pangkal yang sama. Yang mana titik pangkal tersebut disebut titik sudut dan 2 sinar garis itu dinamakan dengan sisi-sisi sudut. Jenis-jenis sudut antara lain (1) sudut lancip , sudut lancip adalah sudut yang besarnya antara 0 s.d. 90 derajat (0 derajat < Sudut lancip > 90 derajat); (2) sudut Siku-siku; sudut siku-siku adalah sudut yang ukuran nya tepat 90 derajat; (3) sudut Tumpul, sudut tumpul adalah sudut yang ukuran nya antara 90 derajat sampai dengan 180 derajat. 
Selain ketiga jenis sudut diatas kalian juga perlu tahu ada 2 jenis sudut lain yaitu (1) sudut Refleks adalah sudut yang mempunyai ukuran antara 180 360 derajat; (2) sudut Perigon adalah sudut yang mempunyai ukuran tepat 360 derajat atau sering disebut juga satu putaran. Hubungan antar sudut yaitu (1) sudut-sudut saling berkomplemen (berpelengkap) Dua buah sudut dikatakan saling berkomplemen jika jumlah kedua sudut tersebut 90 derajat (membentuk sudut siku-siku); (2) sudut-sudut saling bersuplemen (berpelurus), dikatakan saling bersuplemen jika jumlah dari kedua sudutnya adalah 180 derajat (menghasilkan satu garis lurus). Fakta tentang sudut (1) setiap segitiga mempunyai jumlah ketiga sudut nya adalah 180 derajat; (2) semua segiempat memiliki jumlah keempat sudutnya adalah 360 derajat.

Besar sudut dapat ditentukan atau diukur dengan berbagai cara, di antaranya dengan menggunakan sudut satuan dan yang paling tepat menggunakan sebuah alat yang disebut busur derajat. Besar suatu sudut ditetapkan dengan nama "derajat" yang ditulis dengan tanda nol kecil di belakang angka satuan derajat (.... 0 ). Mengukur dengan busur derajat, busur derajat adalah alat ukur yang menggunakan satuan derajat, besarnya adalah 1800 .

Pengertian sudut di dalam ilmu matematika sudut dapat diartikan sebagai sebuah daerah yang terbentuk karena adanya dua buah garis sinar yang titik pangkalnya saling bersekutu atau berhimpit. Bagian-bagian pada suatu sudut, sudut memiliki tiga bagian penting, yaitu (1) kaki sudut adalah garis sinar yang membentuk sudut tersebut; (2) titik sudut adalah titik pangkal/ titik potong tempat berhimpitnya garis sinar; (3) daerah sudut adalah daerah atau ruang yang ada diantara dua kaki sudut.

Jenis-jenis Sudut, ada beragam jenis sudut semuanya dibedakan berdasarkan besar dari daerah sudut yang terbentuk, diantaranya (1) sudut Sikusiku adalah sebuah sudut yang memiliki besar daerah sudut $90^{\circ} ;(2)$ sudut lancip adalah sebuah sudut yang memiliki besar daerah sudut diantara $0^{\circ}$ dan $90^{\circ}\left(0^{\circ}<\mathrm{D}\right.$ $<90^{\circ}$ ); (3) sudut tumpul adalah sebuah sudut yang memiliki besar daerah sudut diantara $90^{\circ}$ dan $180^{\circ}\left(90^{\circ}<\mathrm{D}<180^{\circ}\right)$; (3) sudut lurus adalah sebuah sudut yang memiliki besar daerah sudut $180^{\circ}$; (4) sudut refleks adalah sebuah sudut yang memiliki besar daerah sudut diantara $180^{\circ}$ dan $360^{\circ}\left(180^{\circ}<\mathrm{D}<360^{\circ}\right)$.

Hubungan antar Sudut yaitu (1) sudut berpenyiku, apabila ada dua buah sudut berhimpitan dan membentuk sudut siku-siku, maka sudut yang satu akan menjadi sudut penyiku bagi sudut yang lain sehingga kedua sudut tersebut dinyatakan sebagai sudut yang saling berpenyiku (komplemen); (2) sudut berpelurus, apabila ada dua buah sudut yang berhimpitan dan saling membentuk sudut lurus maka sudut yang satu akan menjadi sudut pelurus bagi sudut yang lain sehingga kedua sudut tersebit bisa dikatakan sebagai sudut yang saling berpelurus (suplemen).

Hubungan antar sudut apabila dua garis sejajar dipotong oleh garis lain yaitu (1) sudut sehadap (sama besar) adalah sudut yang memiliki posisi yang sama dan besarnyapun sama; (2) sudut dalam berseberangan (sama besar) adalah sudut yang ada di bagian dalam dan posisinya saling berseberangan; (3) sudut luar berseberangan (sama besar) adalah sudut yang berada di bagian luar dan posisinya saling berseberangan; (4) sudut dalam sepihak adalah sudut yang berada di bagian 
dalam dan berada pada sisi yang sama. bila dijumlahkan, sudut yang saling sepihak akan membentuk sudut $180^{\circ}$; (5) sudut luar sepihak adalah sudut yang berada di bagian luar dan berada pada sisi yang sama. bila dijumlahkan, sudut yang saling sepihak akan membentuk sudut $180^{\circ}$; (5) sudut bertolak belakang (sama besar)mmerupakan sudut yang posisinya saling bertolak belakang. Satuan sudut, di dalam ukuran derajat, nilai 1 derajat mewakili sebuah sudut yang diputar sejauh $1 / 360$ putaran. artinya $1^{\circ}=1 / 360$ putaran. Untuk menyatakan ukuran sudut yang lebih kecil dari derajat $\left(^{\circ}\right)$ kita bisa menggunakan menit (') dan detik ("). perhatikan hubungan derajat, menit, dan detik berikut ini:1 derajat $\left(1^{\circ}\right)=60$ menit $\left(60^{\prime}\right) ; 1$ menit $\left(1^{\prime}\right)=1 / 60^{\circ} ; 1$ menit $\left(1^{\prime}\right)=60$ detik $\left(60^{\prime \prime}\right) ; 1$ derajat $\left(1^{\circ}\right)=3600$ $\operatorname{detik}(3600 ") ; 1 \operatorname{detik}(1 ")=1 / 3600$.

Adapun media yang digunakan pada materi ini menurut bahan pembuatannya tergolong media sederhana karena bersifat murah dan mudah memperolehnya. Media ini berbentuk sudut siku-siku. Bahan dan alat yang diperlukan yaitu kertasburam/HVS, spidol, penggaris, gambar sudut siku-siku.

\section{Langkah-Langkah Pembuatan Sudut Siku-siku}

Adapun langkah-langkah pembuatan sudut siku-siku yaitu (1) lipat kertas ke arah sembarang menjadi 2 bagian, (2) lipat lagi tegak lurus dengan lipatan 1(pertemuan 2 lipatan membentuk sudut siku-siku yang besarnya $90^{\circ}$ ). Cara penggunaan: letakkan sudut siku-siku dari selembar kertas pada sudut yang akan kita tentukan, jika sudut pada gambar besarnya sama dengan sudut yang kita buat maka disebut sudut siku-siku, jika sudut pada gambar besrnya kurang dari $90^{\circ}$ maka disebut sudut lancip, jika sudut pada gambar besarnya lebih dari $90^{\circ}$ disebut sudut tumpul.

Kelebihan media ini adalah semua bahan dan peralatannya mudah didapat, bentuknya sederhana, mudah dibuat, dan mudah digunakan. Sedangkan kelemahannya karena media terbuat dari kertas maka mudah rusak/robek dan mudah hancur jika terkena air. Matematika merupakan ilmu pasti dan konkret, artinya matematika menjadi ilmu yang real yang bisa diaplikasikan secara langsung dalam kehidupan sehari-hari dalam berbagai bentuk.

\section{Matematika}

Matematika merupakan dasar bagi ilmu-ilmu lain, terutama ilmu yang berkutat dengan angka dan hitung-hitungan, sehingga mempelajari matematika secara tidak langsung juga membuka pintu bagi ilmu-ilmu eksak lainnya untuk dipelajari. Bagi sebagian orang matematika memang dianggap sulit, dan rasa sulit tersebut sebenarnya adalah persepsi yang terbentuk oleh lingkungan bahwa matematika itu sulit, persepsi inilah yang harus dihilangkan. Hal yang paling penting dalam pengajaran matematika adalah dilakukan dengan cara yang asyik dan menyenangkan, sehingga membuat anak betah karena seperti sedang bermain.

Kunci suatu pelajaran agar mudah diterima siswa adalah bagaimana pelajaran tersebut bisa menyenangkan siswa, dan itu semua bisa dicapai salah satunya melalui penggunaan alat peraga. Dengan bantuan alat peraga, siswa menjadi senang, jauh dari kebosanan, pelajaran mudah diterima siswa sehingga 
menjadi pelajaran yang tidak menakutkan serta berpeluang untuk dicintai,dan dapat membangkitkan prestasi belajar siswa di sekolah dasar (Jannah, 2011).

\section{KESIMPULAN}

Matematika merupakan ilmu pasti dan konkret, artinya matematika menjadi ilmu yang real yang bisa diaplikasikan secara langsung dalam kehidupan sehari-hari dalam berbagai bentuk. Kunci suatu pelajaran agar mudah diterima siswa adalah bagaimana pelajaran tersebut bisa menyenangkan siswa, dan itu semua bisa dicapai salah satunya melalui penggunaan alat peraga. Dengan bantuan alat peraga, siswa menjadi senang, jauh dari kebosanan, pelajaran mudah diterima siswa sehingga menjadi pelajaran yang tidak menakutkan serta berpeluang untuk dicintai,dan dapat membangkitkan prestasi belajar siswa di sekolah dasar

\section{SARAN}

Memperhatikan peran guru dan tugas guru sebagai salah satu faktor determinan bagi keberhasilan pendidikan, terutama dalam prestasi belajar, maka keberadaan dan peningkatan profesi guru menjadi wacana yang sangat penting. Kemerosotan pendidikan bukan diakibatkan oleh kurikulum tetapi oleh kurangnya kemampuan profesionalisme guru dan keengganan belajar siswa.

\section{DAFTAR RUJUKAN}

Asmani, Jamal Makmur. 2010. Tips Efektif Aplikasi KTSP di Sekolah. Jogyakarta: Bening.

Jannah, Raodatul. 2011. Membuat Anak Cinta Matematika dan Eksak Lainnya. Yogyakarta: DIVA PRESS.

Mulyasa. 2005. Menjadi Guru Profesional. Bandung: Remaja Rosdakarya.

Peningkatan Profesionalisme Guru Menghadapi Pendidikan Abad ke-21n (I); Organisasi \& Profesi. Suara Guru No. 7/1998.

Putra, Sitiatava Rizema. 2012. Berbagai Alat Bantu untuk Memudahkan Belajar Matematika. Yogyakarta: DIVA PRESS.

Tim Penyusun Kamus Pusat Pembinaan dan Pengembangan Bahasa. 1989. Kamus Besar Bahasa Indonesia. Jakarta: Balai Pustaka Surya, H.M. 1998. 